\title{
The Effects of Psychological Contract Violations in Organizations on Organizational Trust and Alienation: An Application in the Healthcare Sector"
}

\author{
Mustafa Demirkıran ${ }^{1}$ \\ Suleyman Demirel \\ University
}

\author{
Serap Taşkaya ${ }^{2}$ \\ Aksaray University
}

\author{
Mehmet Yorulmaz ${ }^{3}$ \\ Selcuk University
}

\begin{abstract}
Concepts such psychological contract, trust, and alienation are of great importance for organizations today. Due to the unique characteristics of healthcare services in particular, healthcare employees are adversely affected by such concepts, which may result in an even heavier burden. The objective of this research was to determine the effects of healthcare employees' perceptions toward psychological contract violations on their organizational trust and alienation levels. For this purpose, a survey was conducted on 110 employees working in a public hospital in the province of Konya, Turkey. According to this study's findings, while organizational trust was found to decrease and organizational alienation increased as participants' perceived psychological contract violation increased, organizational alienation was found to decrease as trust in one's manager and colleagues increased.
\end{abstract}

\section{Keywords}

Psychological contract $\bullet$ Organizational trust $\bullet$ Alienation

\footnotetext{
* This paper was revised after being presented at the International Journal of Health Administration and Education Congress, İstanbul, Turkey, March 28-29, 2015.

1 Correspondence to: Mustafa Demirkıran (PhD), School of Occupational Collage, Department of Health Care Management, Süleyman Demirel University, Isparta, Turkey. Email: m-demirkiran@hotmail.com

2 School of Health Collage, Department of Health Care Management, Aksaray University, Aksaray, Turkey. Email: seraptaskaya@yahoo.com

3 Department of Health Care Management, Faculty of Health Sciences, Selçuk University, Konya, Turkey. Email: mtyorulmaz@hotmail.com
}

Citation: Demirkıran, M., Taşkaya, S., \& Yorulmaz, M. (2016). The effects of psychological contract violations in organizations on organizational trust and alienation: An application in the healthcare sector. Sanitas Magisterium, 2, 85-95. http://dx.doi.org/10.12738/SM.2016.2.0022 
There are two forms of employment relationships in organizations: formal contracts and psychological contracts. Formal contracts incorporate formal relationships between managers and other employees, which are formally observable and measurable. Psychological contracts, however, are related to behavioral relationships between the specified parties, and although they cannot be seen, they certainly exist (Tipples \& Krivokapic-Skoko, n.d., p. 1). The psychological contract is defined as "the sum of unwritten, unspoken expectations between an individual and a business" (Arslan \& Ulaş, 2004, p. 103) and is a concept related to perceptions, beliefs, expectations, promises, and obligations (Guest, 1998, p. 651). This concept is particularly important in the establishment of positive relationships between the organization and its employees in today's work life. Psychological contracts are a part of employment relationships beginning from the first stage of the recruitment process (Özler \& Ünver, 2012, p. 326). Since psychological contracts consist of individuals' personal perceptions and since perceptions vary from person to person, psychological contracts are subjective (Kirel, 2003, p. 278; Şahin, 2010, p. 97). Employees' perceptions of psychological contract violations can emerge in various ways. According to Morrison and Robinson (1997, p. 240), employees compare the organization's promises and the degree of their being fulfilled, and if they feel that the result of this comparison is to their disadvantage, they perceive a breach to the psychological contract. Since when an employee perceives that his employing organization has violated the psychological contract, he may not want to fulfill the contractual obligations required of him, adverse changes may occur in employees' attitudes and behaviors toward their employing organization (Kirel, 2003, p. 281).

One of the concepts held to be associated with perceptions of psychological contract violation is organizational trust. Trust is defined as "the confidence in a person's purpose, expectations, and words, on the one hand, or the willingness to commit to people, believing in their words and behaviors, on the other" (Memduhoğlu \& Zengin, 2010, p. 261). Organizational trust involves an employee's trust in his employing organization, manager, and colleagues (Büte, 2011, p. 175). Since organizational trust plays an important role in the happiness and enthusiasm levels of employees while they are working (Şakar, 2010, p. 35), it is more than just an important element of modern organizations, it is considered as the very glue that holds everything together (Barutçugil, 2002, p. 104). Employees working for organizations with a high level of trust solve problems and overcome obstacles more easily (Barutçugil, 2002, p. 100). Trust enables employees to freely express their thoughts and feelings, improves organizational communication, and strengthens solidarity and team spirit, resulting in a positive effect on employees' performances (Memduhoğlu \& Zengin, 2010, p. 261). Creating an environment of trust, which is of utmost importance in organizational terms, requires a long period of time to achieve. Organizations can earn trust by keeping their promises in the long term. In other words, promises made should be fulfilled in a consistent manner in order for the organization to earn its employees’ trust (İslamoğlu, Birsel, \& Börü, 2007, p. 131). 
Another concept held to be associated with perceptions of psychological contract violation is organizational alienation. People who spend a significant portion of their lives at work should normally feel integrated into their organization and work environment. However, this is not always the case. It is occasionally observed that some employees are neither happy nor content at work and find themselves alienated from their employing organization (Şirin, 2009, p. 166). The concept of alienation, which represents “a person's feelings of separation or isolation from his or her work, environment, or self” (Ünsar \& Karahan, 2011, p. 361), has two different meanings. The first one is in a socio-psychological sense; when an individual is estranged from his organization or group and no longer feels a sense of belonging to that organization. The second is in a philosophical sense; when an individual is transformed into an object and loses his or her identity (Bell, 1959, p. 933). There are several causes of employees' feeling alienated from their employing organization, which include work conditions (Banai et al., 2004, p. 377), routine work (Ulusoy, 1988), the employee's inability to control the word work he does or to realize himself, and organizational health problems (Tutar, 2010, p. 177, 183). As in the case of organizational mistrust, alienation entails serious negative effects on organizations, including an increased tendency of employees to quit their job (Ünsar \& Karahan, 2011), organizational health problems, increased failure and work-related stress (Tutar, 2010, p. 177), decreased productivity (Ünsar \& Karahan, 2011, p. 361), job satisfaction and performance, and the potential to cause a decline in a person's distinguishing characteristics (Tutar, 2010).

It is apparent that such concepts as psychological contract, trust, and alienation are of great importance for organizations today. Due to the unique characteristics of healthcare services in particular and because the healthcare sector is a sector directly related to human life, healthcare employees are adversely affected by such concepts, which may result in a heavier burden on them.

\section{Method}

\section{Purpose and Importance of the Study}

This study has aimed to determine the effects of hospital employees' perceptions toward psychological contract violation on their organizational trust and alienation levels. Healthcare workers who are not alienated from and who trust their employing institutions will no doubt improve the quality and efficiency of their services. Given that the healthcare services are directly related to human health, it becomes much more important that such services should be provided by employees experiencing lower levels of alienation and who trust their employing institution. The objective of the present research is to establish the effects of the hospital staff's perceptions toward psychological contract violation on their levels of trust in and alienation from their employing institution. 


\section{Universe and Sample}

The population of the study consisted of the employees (physicians, midwives, nurses, $\mathrm{x}$-ray - laboratory technicians and administrative staff) of a public hospital in the province of Konya, Turkey. No samples were selected in the study as it was aimed to reach all 165 hospital employees with the foregoing titles. At the end of the study, a total of 110 questionnaires were completed and returned, making the response rate $66.6 \%$.

\section{Data Collection Tool}

The survey method was used to collect data for the study. The questionnaire consisted of three parts. The first part contained a 4-item scale measuring perceptions of psychological contract violation developed by Robinson and Morrison (2000). The organizational trust scale developed by Tokgöz (2012) utilizing a variety of previous studies (Mayer et al., 1995; McAllister, 1995; Whitener et al., 1998) was included in the second part. This scale consisted of three dimensions: (1) trust in the organization, (2) trust in the manager, and (3) trust in colleagues. The third part of the questionnaire contained statements relating to organizational alienation. These statements were either directly or indirectly obtained from various references (Aiken \& Hage, 1966; Banai \& Weisberg, 2003; Huang, 2006; Hsiung, 1990; Kohn, 1976; Mottaz, 1981; Nettler, 1957; Ofluoğlu \& Büyükyılmaz, 2008; Özçınar, 2001; Seeman, 1967; Wang, 1991) as a result of a literature search performed by the researcher. The last part of the data collection tool contained open and closed-ended questions related to the personal and professional characteristics of the employees. A 5-point Likert scale was used to evaluate the items in the first three parts of the questionnaire.

The Cronbach's Alpha confidence coefficients of the scale measuring perceptions of psychological contract violation, the organizational trust scale, the organizational alienation scale were $.97, .98$, and 0.98, respectively. Since the Cronbach's Alpha values were less than $60 \%$, the scales can be said to have statistically acceptable confidence levels.

\section{Findings}

A total of 110 individuals participated in the study, which was conducted on physicians, other health professionals (midwives, nurses, and x-ray - laboratory technicians) and administrative staff of a public hospital in Turkey, and the distribution of respondents' socio-demographic characteristics is given in Table 1.

When the distribution of the hospital employees by gender is examined, it is seen that $55.5 \%$ of the respondents were female and that $80.9 \%$ of the employees were married. In view of their educational status, it is seen that most of the employees had earned a BSc degree (47.3\%), followed by those with an associate degree $(38.2 \%)$. 
The majority of the respondents were between the ages of 26 and 35 . When the results are examined in terms of total length of service, it is clear that the high minority of employees length of employment ranged between 11 and 15 years (44.5\%).

\begin{tabular}{lcc}
\hline Table 1 & & \\
Distribution of the Respondents by Socio-Demographic Characteristics & & \\
\hline Variables & & \\
\hline Gender & 61 & 55.5 \\
Female & 49 & 44.5 \\
Male & & \\
Marital Status & 89 & 80.9 \\
Married & 21 & 19.1 \\
Unmarried & & \\
Educational Status & 6 & 5.5 \\
High School & 42 & 38.2 \\
Associate Degree & 52 & 47.3 \\
Bachelor's Degree & 10 & 9.1 \\
MSc/PhD/TUS (the exam for medical specialization) & & \\
Age & 22 & 20.0 \\
25 and younger & 44 & 40.0 \\
26-35 & 37 & 33.6 \\
45 and older & 37 \\
Length of Service & 6 & 5.5 \\
Less than 5 years & & \\
6-10 years & 18 & 16.4 \\
11-15 years & 32.7 \\
More than 16 years & 36 & 34.5 \\
\hline
\end{tabular}

Table 2 shows the respondents' assessments related to the study's variables. According to this table, the mean $(3.06 \pm 1.02)$ for hospital employees' perceptions of psychological contract violation was slightly above the midpoint. Hospital employees' levels of organizational trust $(2.68 \pm 0.70)$ was close to the mean and lower, as compared to the other variables, whereas their level of organizational alienation $(3.50 \pm 0.76)$ was higher. As for the skewness and kurtosis values observed in Table 2 showing whether the data are normally distributed, the skewness values ranged between -0.37 and -0.79 and the kurtosis values ranged between -0.14 and -0.75 .

Table 2

The Respondents' Assessments related to Psychological Contract Violation, Organizational Trust, and Organizational Alienation

\begin{tabular}{lccccc}
\hline & $\mathbf{n}$ & Mean & S. Deviation & Skewness & Kurtosis \\
\hline Psychological Contract Violation & 110 & 3.06 & 1.02 & -0.37 & -0.75 \\
Organizational Trust & 110 & 2.68 & 0.70 & 0.68 & -0.20 \\
Organizational Alienation & 110 & 3.50 & 0.76 & -0.79 & -0.14 \\
\hline
\end{tabular}


According to Table 3, which shows the respondents' socio-demographic characteristics and the effects of their perceptions toward psychological contract violation on their organizational trust levels, the model accounted for only $25 \%$ of the assessments related to perceived organizational trust. In terms of its significance level, it is clear that the model was significant at all levels as a whole $(F=8.137 ; p=.000)$. The Durbin Watson coefficient, used to test whether there is any autocorrelation in the model, was 2.174, and Durbin Watson values ranging from 1.5 to 2.5 showed that there was no autocorrelation. Another important statistic observed in Table 3 is the VIF indicating whether there is any multicollinearity problems in the model. The VIF values ranged from 1.055 to 1.227 , showing that there no multicollinearity existed between independent variables. Table 3 also lists the parameter values of the model obtained as a result of estimation and related statistics values and significance levels.

According to the table, those with a high level of education tend to have greater trust in the organization. Those employees with 11 to 15 years of service had lower levels of trust. Those whose ages ranged from 36 to 45 (with more than 15 years of service) had higher levels of trust. Additionally, trust in the organization decreased as one's perception of psychological contract violation increased. Standardized beta coefficients demonstrated that the effect of having a post-graduate degree on one's trust in his organization $(\beta=.349)$ was higher when compared to the other variables.

\begin{tabular}{|c|c|c|c|c|}
\hline \multicolumn{5}{|l|}{ Table 3} \\
\hline \multicolumn{5}{|c|}{$\begin{array}{l}\text { Findings related to the Effects of Respondents' Socio-Demographic Characteristics and Their Perceptions } \\
\text { toward Psychological Contract Violation on Their Organizational Trust Levels }\end{array}$} \\
\hline \multirow[b]{2}{*}{ Independent Variables } & \multicolumn{4}{|c|}{ Dependent Variable: Organizational Trust } \\
\hline & Std. $\beta$ coefficient & $t$ & $p$ & VIF \\
\hline (Fixed ) & & 13.521 & .000 & \\
\hline Post-graduate degree & .349 & 3.896 & .000 & 1.160 \\
\hline Bachelor's Degree & .314 & 3.407 & .001 & 1.227 \\
\hline Length of Service (11-15) & -.277 & -3.183 & .002 & 1.094 \\
\hline $\operatorname{Age}(36-45)$ & .210 & 2.454 & .016 & 1.055 \\
\hline \multirow[t]{2}{*}{ Psychological Contract Violation } & -.224 & -2.588 & .011 & 1.084 \\
\hline & $\mathrm{R} 2=.247$ & $F=8.137$ & $p=.000$ & Durbin- Watson $=2.174$ \\
\hline
\end{tabular}

According to Table 4, the generated model accounted for $53.8 \%$ of the hospital employees' assessments related to organizational alienation. Since the test revealed the significance level of the model as a whole $(\mathrm{F}=32.741 ; p=.000)$, it is of significance. While the Durbin Watson coefficient for the model $(\mathrm{DW}=1.551)$ ranged between 1.5 and 2.5, indicating no autocorrelation problems, the VIF values were very small figures of less than 10, ranging from 1.055 to 1.071 , indicating no multicollinearity problems. 
Table 4

Findings related to the Effects of the Respondents'Socio-Demographic Characteristics, Perceptions toward Psychological Contract Violation, and Organizational Trust Levels on Their Alienation Levels

\begin{tabular}{lcccc}
\hline & \multicolumn{4}{c}{ Dependent Variable: Organizational Alienation } \\
\cline { 2 - 5 } Independent Variables & Std. $\beta$ coefficient & $t$ & $p$ & VIF \\
\hline (Fixed ) & -.377 & 8.084 & .000 & 1.071 \\
\hline Trust in the Manager & -.398 & -5.591 & .000 & 1.025 \\
\hline Trust in Colleagues & .371 & 6.043 & .000 & 1.077 \\
\hline Psychological Contract & -.168 & -2.506 & .014 & 1.055 \\
\hline Age $(46+)$ & $\mathrm{R} 2=.538$ & $\mathrm{~F}=32.741$ & $p=.000$ & Durbin- Watson $=1.551$ \\
\hline
\end{tabular}

As a result of the stepwise regression analysis performed, the independent variables introduced into the model showed that age (46 years and above) had a significant effect on participants' sense of alienation from the organization $(p<.05)$. Those employees aged 46 years and older displayed a lower level of alienation from the organization. In addition, trust in the manager and colleagues, both dimensions of organizational trust, as well as participants' perception of psychological contract violation affected organizational alienation. Accordingly, while alienation from the organization decreased as one's trust in his manager and colleagues increased, it increased as one's perception of psychological contract violation increased.

\section{Discussion, Results, and Recommendations}

This study was conducted in order to reveal psychological contracts' importance in work life, on the one hand, and the correlation between hospital employees' perceptions of psychological contract violation and their levels of organizational trust and organizational alienation, on the other.

A total of 110 individuals participated in the current study, which was conducted in a public hospital. As a result of the study, the hospital employees were found to have a moderate level of perceived psychological contract violation (3.06 \pm 1.02$)$. Similarly, a study by Mimaroğlu (2008) conducted on 457 medical sales representatives in Turkey and a study by Katrinli et al. (2011) conducted on 148 nurses in a private hospital in Turkey reported lower levels of perceived psychological contract violation (2.64 and 1.82, respectively).

At the end of this study, it was determined that the hospital employees' levels of organizational trust $(2.68 \pm 0.70)$ were below moderate. Similarly, in a study by Top (2012) conducted on 304 physicians and 254 nurses working in 5 teaching and research hospitals in Istanbul, the level of organizational trust (3.85/7-point Likert) was found to be below moderate. On the contrary, higher levels (5.06/7-point Likert scale) of organizational trust were reported by Tokgöz and Seymen (2013) in their 
study conducted on 220 employees in 2 hospitals in Balikesir province. Durukan et al. (2010) conducted a study on 138 nurses in a university hospital in Ankara, whose results were 3.55 on a 5-point Likert scale. Moreover, Bahrami et al. (2012) conducted a study on 165 nurses in a healthcare center in Iran, whose results were between 3.00 to 3.31 on a 5-point Likert scale.

The current study also found that the hospital employees' levels of organizational alienation $(3.50 \pm 0.76)$ were above moderate. Consistent with this result, previous studies conducted in Turkey, including a study by Yardan, Demirkıran, and Yeşilyurt (2014) conducted on the medical staff at a teaching and research hospital in Turkey $(n=149)$, a study by Yetiş (2013) conducted on nurses from 4 hospitals in Erzurum ( $\mathrm{n}=593$ ), a study by Usul and Atan (2014) conducted on the medical staff at Konya Teaching and Research Hospital $(n=150)$, a study by Daryemez (2010) conducted on the medical staff of Baskent University Hospital in Ankara $(n=60)$, found alienation levels above 3 , which is the medium level.

According to the findings of the current study, organizational trust decreased and organizational alienation increased as participants' perception of psychological contract violation increased. Yet, organizational alienation decreased as participants' trust in their manager and colleagues increased. These results fit well with study's hypotheses as well as the literature. Similarly, in a study conducted on 350 pharmaceutical company representatives from Konya, Yilmaz (2012) identified a moderate negative correlation between perceived psychological contract violation and organizational trust. Similarly, in a study by Robinson (1996) conducted on 125 managers from various institutions in the United States, managers' perceptions toward psychological contract violation were found to significantly affect organizational trust. İşçi, Taştan, and Akyol (2013) established a moderate negative correlation between organizational trust and the level of alienation in their study conducted on 128 employees and 15 managers from 4 hospitals in Istanbul.

In conclusion, managers should be aware of the importance of psychological contracts in increasing their employees' levels of organizational trust and in decreasing their levels of alienation. Psychological contracts can vary from person to person. Therefore, managers should try to understand their employees and provide them with a business environment so that they can express their expectations. Both sides should be open and in constant communication with each other and make a concerted effort to fulfill their promises. 


\section{References}

Aiken, M., \& Jerald, H. (1966). Organizational alienation: A comparative analysis. American Sociological Review, 31(4), 497-507.

Arslan, H. B., \& Ulaş, D. (2004). İstihdamın korunması ve işten çıkarılanlara uygulanan yardimlar [Protection of employment and aid programs applied to rebundants]. Ege Akademik Bakış Dergisi, 4(1), 102-114.

Bahrami, S., Hasanpour, M., Rajaeepour, S., Aghahosseni, T., \& Hodhodineghad, N. (2012). The relationship between organizational trust and nurse administrators' productivity in hospitals. Iranian Journal of Nursing and Midwifery Research, 17(6), 451-455.

Banai, M., \& Weisberg, J. (2003). Alienation in the private and the public sectors in Russia. Scandinavian Journal of Management, 19(3), 359-383.

Banaia, M., Reiselb, W. D., \& Probstc, T. M. (2004). A managerial and personal control model: Predictions of work alienation and organizational commitment in Hungary. Journal of International Management, 10, 375-392.

Barutçugil, İ. (2012). Organizasyonlarda duyguların yönetimi [Management of emotions in organizations]. İstanbul, Turkey: Kariyer Yayınc1lı.

Bell, D. (1959). The "rediscovery" of alienation: Some notes along the quest for the historical Marx. The Journal of Philosophy, 56(24), 933-952.

Büte, M. (2011). Etik iklim, örgütsel güven ve bireysel performans arasındaki ilişki. Atatürk Üniversitesi Iktisadi ve İdari Bilimler Dergisi, 25(1), 171-192.

Darıyemez, K. (2010). Örgütlerde ortaya çıkan yabancilaşma sorunu ve bu sorunun çözümü açısından halkla ilişsiler çalışmalarının önemi (Başkent Üniversitesi Ankara Hastanesi örneği) [Arising in the alienation of organizations and problems solution in terms of this question study importance of public relations, Baskent University Ankara Hospital case] (Master's thesis, Başkent University, Ankara, Turkey). Retrieved from https://tez.yok.gov.tr/UlusalTezMerkezi/

Durukan, S., Akyürek, Ç., \& Coşkun, E. (2010). Hacettepe Üniversitesi Erişkin Hastanesi'nde çalışan hemşirelerin örgütsel güven, güçlendirme ve bağlılık düzeylerinin belirlenmesi [The determination of organizational trust, empowerment and commitment levels of nurses working at Hacettepe University Adult Hospital]. Süleyman Demirel Üniversitesi İktisadi ve İdari Bilimler Fakültesi Dergisi, 15(3), 411-434.

Guest, D. E. (1998). Is the psychological contract worth taking seriously? Journal of Organizational Behavior, 19, 649-664.

Huang, Y. C. (2006). The relationships among job satisfaction, professional commitment, organizational alienation, and coaching efficacy of school volleyball coaches in Taiwan (Doctoral dissertation, United States Sports Academy, Alabama, United States of America).

İslamoğlu, G., Birsel, M., \& Börü, D. (2007). Kurum içinde güven [Trust in institution]. İstanbul, Turkey: İnk1lap Kitabevi.

İşçi, E., Taştan, S. B., \& Akyol, Ç. (2013). Örgütsel güvenin işe yabancılaşma üzerindeki etkisinde yöneticinin iletişim becerisinin rolü: Özel hastane çalışanları örneği [The role of managerial communication skills on the effect of organizational trust on job alienation: A case of private hospital employees]. Uluslararası Hakemli Beşeri ve Akademik Bilimler Dergisi, 2(3), 95-113.

Katrinli, A., Atabay, G., Gunay, G., \& Cangarli, B. G. (2011). The moderating role of leadermember exchange in the relationship between psychological contract violation and organizational citizenship behavior. African Journal of Business Management, 5(1), 1-6. 
Kırel, Ç. (2003). İş ilişkileri, kariyer ve toplumsallaşma sürecinde kariyerin önemi [Business relations, career and importance of career in the socialization process]. In E. Özkalp (Ed.), Örgütsel davranış [Organizational behavior] (pp. 277-292). Eskişehir, Turkey: Anadolu Üniversitesi Açıöğretim Fakültesi Yayınları.

Kohn, M. L. (1976). Occupational structure and alienation. The American Journal of Sociology, 82(1), 111-130.

Mayer, R. C., Davis, J. H., \& Schoorman, F. D. (1995). An integrative model of organizational trust. Academy of Management Review, 20(3), 709-734.

McAllister, D. J. (1995). Affect-and cognition- based trust as foundations for interpersonal cooperation in organizations. Academy of Management Journal, 38(1), 24-59.

Memduhoğlu, H. B., \& Zengin, M. (2010). Örgütsel güven [Organizational trust]. In H. B. Memduhoğlu \& K. Yılmaz (Eds.), Yönetimde yeni yaklaşımlar [New approaches in management] (pp. 261-273). Ankara, Turkey: Pegem Akademi Yayınevi.

Mimaroğlu, H. (2008). Psikolojik sözleşmenin personelin tutum ve davranışlarına etkileri: Tibbi satış temsilcileri üzerinde bir araştırma [Effects of psychological contract on personnel attitudes and behaviors: A study on medical sales people] (Doctoral dissertation, Çukurova University, Adana, Turkey). Retrieved from https://tez.yok.gov.tr/UlusalTezMerkezi/

Morrison, E. W., \& Robinson, S. L. (1997). When employees feel betrayed: A model of how psychological contract violation develops. The Academy of Management Review, 22(1), 226-256.

Mottaz, C. L. (1981). Some determinants of work alienation. The Sociological Quarterly, $22(4), 515-529$.

Nettler, G. (1957). A measure of alienation. American Sociological Review, 22(6), 670-677.

Ofluoğlu, G., \& Büyükyılmaz, O. (2008). Türkiye Taşkömürü Kurumu Kozlu İşletme Müessesesinde yabancılaşmanın boyutları üzerinde etkili olan nedenlerin araştırılması [Investigating the factors effecting on the dimensions of alienation of employees who works in Kozlu business enterprises of coal in Turkey]. Kamu İs, 9(4), 1-43.

Özçınar, M. (2011). Örgütlerde yabancılaşma ile tükenmişlik sendromu arasındaki ilişsiyi belirlemeye yönelik bir araştırma [A research in order to determine the relationship between alienation and burnout syndrome in the organizational] (Master's thesis, Dumlupinar University, Kütahya, Turkey). Retrieved from https://tez.yok.gov.tr/UlusalTezMerkezi/

Özler, D. E., \& Ünver, E. (2012). Psikolojik sözleşmenin iş tatmini üzerindeki etkisini belirlemeye yönelik bir araştırma [A research to analyze the impact of psychological contract on job satisfaction]. Süleyman Demirel Üniversitesi İktisadi ve İdari Bilimler Fakültesi Dergisi, 17(2), 325-351.

Robinson, S. L. (1996). Trust and breach of the psychological contract. Administrative Science Quarterly, 41(4), 574-599.

Robinson, S. L., \& Morrison, E. W. (2000). The development of psychological contract breach and violation: A longitudinal study journal of organizational behavior. Journal of Organizational Behaviour, 21, 525-546.

Seeman, M. (1967). On the personnel consequences of alienation in work. American Sociological Review, 32(2), 273-285.

Şahin, M. D. (2010). Psikolojik sözleşme [Psychological contract]. In D. E. Özler (Ed.), Örgütsel davranışta güncel konular [Contemporary topics in organizational behavior] (pp. 81-99). Bursa, Turkey: Ekin Yayınevi.

Şakar, N. (2010). Örgütsel güven [Organizational trust]. In D. E. Özler (Ed.), Örgütsel davranışta güncel konular [Contemporary topics in organizational behavior] (pp. 21-40). Bursa, Turkey: Ekin Yayınevi. 
Şirin, E. F. (2009). Beden eğitimi öğretmenlerinin işe yabancılaşma düzeylerinin bazı değişkenler açısından incelenmesi [The search of physicial education teachers work alienation level according to some variables]. Celal Bayar Üniversitesi Beden Eğitimi ve Spor Bilimleri Dergisi, 4(4), 164-177.

Tipples, R., \& Krivokapic-Skoko, B. (n.d.). University academics' psychological contracts in Australia and New Zealand. Retrieved from http://www.mngt.waikato.ac.nz/departments/ Strategy\%20and\%20Human\%20Resource\%20Management/airaanz/proceedings/ auckland2007/076.pdf

Tokgöz, E. (2012). Örgütsel güven, örgütsel özdeşleşme ve örgütsel vatandaşlık davranışı arasındaki ilişki [Relationship between organizational trust, organizational identification and organizational citizenship behavior] (Master's thesis, Balıkesir University, Balıkesir, Turkey). Retrieved from https://tez.yok.gov.tr/UlusalTezMerkezi/

Tokgöz, E., \& Seymen, O. A. (2013). Örgütsel güven, örgütsel özdeşleşme ve örgütsel vatandaşlık davranışı arasındaki ilişki: Bir devlet hastanesinde araştırma [Relationship between organizational trust, organizational identification and organizational citizenship behavior: A study at a state hospital]. Öneri, 10(39), 61-76.

Top, M. (2012). Hekim ve hemşirelerde örgütsel bağlılık, örgütsel güven ve iş doyumu profili [The profile of physicians' and nurses' organizational commitment, organizational trust and job satisfaction]. İstanbul Üniversitesi Işletme Fakültesi Dergisi, 41(2), 258-277.

Tutar, H. (2010). İşgören yabancılaşması ve örgütsel sağlık ilişkisi: Bankacılık sektöründe bir uygulama [The link between employee alienation and organizational health: A case study in the banking sector]. Ankara Üniversitesi SBF Dergisi, 65(1), 175-204.

Ulusoy, H. (1988). Sanayi örgütü işçileri ve işe-yabancılaşma [Industrial organization workers and work alienation]. Ankara Üniversitesi Dil ve Tarih-Coğrafya Fakültesi Dergisi, 32(1-2), 77-84.

Usul, H., \& Atan, A. (2014). Sağl1k sektöründe yabancılaşma düzeyi [The level of alienation in healthcare industry]. Karamanoğlu Mehmetbey Üniversitesi Sosyal ve Ekonomik Araştırmalar Dergisi, 16(26), 1-10.

Ünsar, A. S., \& Karahan, D. (2011). Yabancılaşmanın işten ayrılma eğilimine etkisini belirlemeye yönelik bir alan araştırması [A field study to determine the impact of alienation on turnover intention]. Sosyal ve Ekonomik Araştırmalar Dergisi, 21, 361-378.

Whitener, E. M., Brodt, S. E., Korsgaard, M. A., \& Werner, J. M. (1998). Managers as initiators of trust: An exchange relationship framework for understanding managerial trustworthy behavior. The Academy of Management Review, 23(3), 513-530.

Yardan, E. D., Demirkıran, M., \& Yeşilyurt, A. (2014, September). Ameliyathane, yoğun bakım ve acil birim çalışanlarının çatışma yönetimi algılamalarının kurumsal yabancılaşmaya olan etkisi [The effect of conflict management perceptions of surgery room, intense care and emergency personnel on corporate alienation]. Paper presented at the 8. Sağlık ve Hastane İdaresi Kongresi, Girne.

Yetiş, Z. (2013). Kamu hastanelerinde çalışan hemşirelerde işe yabancılaşma [Alienation for the work of the nurses working in public hospitals] (Master's thesis, Atatürk University, Erzurum, Turkey). Retrieved from https://tez.yok.gov.tr/UlusalTezMerkezi/

Yılmaz, A. (2012). Psikolojik sözleşme ve örgütsel güven arasındaki ilişkinin analizi: Teorik ve uygulamalı bir çalışma [Analysis of the relationship between the psychological contract and organizational trust: A study of theoretical and applied] (Master's thesis, Selçuk University, Konya, Turkey). Retrieved from https://tez.yok.gov.tr/UlusalTezMerkezi/ 
